\title{
FACTOR ANALYSIS AFFECTING THE CAUSE OF MATERNAL DEATH IN PADANG CITY 2017
}

\author{
Nursal Asbiran ${ }^{1}$ Miftah Amalia Yasti ${ }^{2}$ Silvia $^{3}$ \\ 1,2,3 STIKes Fort De Kock Bukittinggi \\ miftahamaliayasti@gmail.com
}

Submitted: 29-11-2017, Reviewer: 05-01-2018, Accepted: 17-10-2018

\begin{abstract}
ABSTRAK
Angka Kematian Ibu Kota Padang tahun 2016 ada 10 kematian maternal disebabkan 3 kasus perdarahan, 2 infeksi serta 5 Hipertensi Dalam Kehamilan. Tujuan penelitian adalah untuk mengetahui Faktor-Faktor apa saja yang Mempengaruhi Penyebab Kematian Maternal di kota Padang tahun 2017. Penelitian bersifat Mixed Metodes dengan design sequential explanatory design dilakukan tanggal 16 Juni sampai 15 Juli 2017 di wilayah kerja Puskesmas se-Kota Padang, DKK Padang dan KUA Kuranji. Sampel berjumlah 49 orang terdiri dari 42 responden dan 7 informan.Pengolahan dan analisis kuantitatif dengan univariat, bivariat dan multivariat sedangkan kualitatif yaitu reduksi data, kategorisasi dan sintesisasi dituangkan bentuk matriks dan diuraikan bentuk narasi. Hasil penelitian tingkat pendidikandan tindakan $7 \mathrm{~T}$ bidan memiliki hubungan pada kematian maternal. Variabel yang paling berpengaruh adalah tindakan $7 \mathrm{~T}$ bidan.Disimpulkan Input, determinanjauh berupa pendidikan berhubungan terhadap kematian maternal. Proses, determinan antara semua program KIA dan KUA belum berjalan maksimal. Output, determinan dekat semua faktor resiko terjadi karena kualitas pelayanan yang diberikan belum optimal. Diharapkan Puskesmas menjalankan semua program KIA secara maksimal dan adanya Kerjasama lintas sektor dengan KUA.
\end{abstract}

Kata Kunci: Angka Kematian Ibu, Penyebab Kematian Maternal, ANC, KIA, KUA

\begin{abstract}
Maternal Mortality Rate of Padang in 2016 there are 10 maternal deaths due to 3 cases of bleeding, 2 infections and 5 Hypertension in Pregnancy. The purpose of this research is to know the Factors influencing the cause of Maternal Death in Padang city in 2017. The research is Mixed Metodes with design sequential explanatory design done on June 16 until July 15, 2017 in working area of Puskesmas as Padang City, DKK Padang and KUA Kuranji. The sample consisted of 49 people consisting of 42 respondents and 7 informants. Processing and quantitative analysis with univariate, bivariate and multivariate while qualitative data reduction, categorization and sintesisasi poured form of matrix and described form of narration. The results of research on the level of education and action of midwife $7 T$ have a relationship to maternal deaths. The most influential variable is the midwife's 7T. Concluded Input, the remote determinant of education related to maternal deaths. The process, the determinant between all KIA and KUA programs has not been maximized. Output, a close determinant of all risk factors occurs because the quality of service provided is not optimal. Puskesmas is expected to run all KIA programs maximally and there is a cross-sectoral Cooperation with KUA
\end{abstract}

Keywords : Maternal Mortality Rate, Cause of Maternal Death, Antenatal Care,Health Of Both Mother And Child, Ministry Of Religion 


\section{PENDAHULUAN}

$\begin{array}{lcr}\text { Angka } & \text { Kematian ibu di } & \text { Indonesia } \\ \text { mencapai } & 228 / 100.000 & \text { kelahiran } \\ \text { hidup.Angka ini jauh lebih tinggi } \\ \text { dibandingkan Vietnam yaitu } 59 / 100.00 \\ \text { kelahiran hidup, dan Cina } 37 / 100.000 \\ \text { kelahiran hidup.Ini menempatkan Indonesia } \\ \text { sebagai salah satu negara dengan angka } \\ \text { kematian Ibu tertinggi di Asia, tertinggi ke- } \\ 3 \text { di kawasan ASEAN dan ke -2 tertinggi di } \\ \text { kawasan SEAR. (WHO, 2013). }\end{array}$

Angka Kematian Ibu (AKI) di Indonesia tahun 2012 adalah 359/100.000 kelahiran hidup, sedangkan pada tahun 2010 diketahui bahwa AKI di Indonesia sebesar 214/100.000 kelahiran hidup dan tahun 2008 adalah 228/100.000 kelahiran hidup. Angka kematian Ibu di Sumatera Barat pada tahun 2012 adalah 104/100.000 kelahiran hidup dan pada tahun 2011 adalah 129/100.000 kelahiran hidup (Survei Demografi dan Kesehatan Indonesia,2012).

McCarthy dan Maine (1992) mengemukakan adanya 3 faktor yang berpengaruh terhadap proses terjadinya kematian maternal. Proses yang paling dekat terhadap kejadian kematian maternal, disebut sebagai determinan dekat yaitu kehamilan itu sendiri dan komplikasi yang terjadi dalam kehamilan, persalinan dan masa nifas (komplikasi obstetri).

Determinan dekat secara langsung dipengaruhi oleh determinan antara yaitu status kesehatan ibu, status reproduksi, akses ke pelayanan kesehatan, perilaku perawatan kesehatan / penggunaan pelayanan kesehatan dan faktor - faktor lain yang tidak diketahui atau tidak terduga.

Determinan jauh yang akan mempengaruhi kejadian kematian maternal melalui pengaruhnya terhadap determinan antara, yang meliputi faktor sosio - kultural dan faktor ekonomi, seperti status wanita dalam keluarga dan masyarakat, status keluarga dalam masyarakat dan status masyarakat.

Tergambar bahwa penyebab terjadinya kematian ibu diantaranya disebabkan oeh perdarahan dan preeklampsia didapatkan pada saat dilakukan diskusi kelompok terarah (Fokus Group Discussion /FGD) pada kegiatan posyandu pada tanggal $6 \mathrm{Mei}$ 2017 di Padang Sarai ternyata hal ini disebabkan oleh pernikahan pada usia dini, dikarena banyaknya status perekonomian keluarga yang masih relatif rendah yang umumnya mereka bekerja sebagai nelayan, tani dan masih banyak sebagai Ibu Rumah Tangga, disamping itu masih banyaknya pasangan menikah dengan status pendidikan berada pada strata Sekolah Menengah Pertama (SMP). PUS dengan jumlah paritas yang lebih dari 3 bahkan ada sampai 9 orang sehingga karena hal ini para orangtua banyak yang melepaskan anaknya untuk menikah lebih cepat pada usia dibawah 20 tahun, alasan berparitas banyak adalah karena suami tak mendukung untuk menggunakan $\mathrm{KB}$ pada istrinya.

Menurut Profil Kesehatan Indonesia tahun 2013, Provinsi Sumatra Barat sesuai data Ditjen Bina Gizi dan KIA, Kemenkes RI 2014, menduduki posisi ke- 11 terendah dari 33 provinsi yang ada di Indonesia dengan tingginya Angka Kematian Ibu. Kasus kematian ibu di Kota Padang dari tahun 2011 sampai 2015 mengalami kenaikan pada 5 tahun terakhir yaitu 16 sampai 15 kematian ibu dan naik pada tahun 2015 naik menjadi 17 kematian ibu. (Profil Kesehatan Kota Padang,2015).

Kota Padang memiliki 22 puskesmas masih banyak memiliki angka kematian ibu yang tinggi serta dari laporan DKK Padang tahun 2016 diketahui penyebab kematian maternal banyak disebabkan oleh penyebab Langsung kematian maternal berupa Perdarahan dan PEB serta Infeksi, sehingga AKI bisa diminimalisir maka peneliti 
tertarik untuk melakukan penelitian mengenai“Analisis Faktor yang Mempengaruhi Penyebab Kematian Maternal di Kota Padang Tahun 2017"

\section{METODE PENELITIAN}

Metode penelitian dengan metode penelitian kombinasi, dengan desain sequential explanatory design (urutan pembuktian). Penelitian kuantitatif adalah dengan desain case control dengan menggunakan kuisioner. Sedangkan penelitian kualitatif dengan melakukan wawancara mendalam atau interview terhadap informan.Pengolahan data Kuantitatif diolah secara komputerisasi. Analisis Data yaitu analisa univariat, Analisa Bivariat dan analisa multivariat.Sedangkan pada kualitatif Data yang telah dikumpulkan dari informan atau Hasil yang diperoleh dituangkan kedalam bentuk matriks. Data yang terkumpul dikelompokkan sesuai dengan kategori dan tujuan penelitan dan setelahnya dilakukan analisis isi.Hasil yang telah diringkas ke dalam bentuk matriks diuraikan kembali ke dalam bentuk narasi untuk kemudian dilakukan konseptualisasi dan konfigurasi data.

\section{HASIL DAN PEMBAHASAN}

Pada Tabel 1 terlihat bahwa tingkat pendidikan ibu pada kelompok kasus ada 3 ibu $(42.9 \%)$ memiliki tingkat pendidikan rendah dan pada ibu kontrol ada 9 ibu memiliki tingkat pendidikan rendah (25.7\%). Dimana tingkat rendah ini adalah ibu tidak menamatkan pendidikan SMU

Tabel 1

Distribusi kasus dan kontrol berdasarkan Tingkat Pendidikan Ibu

\begin{tabular}{cccccc}
\hline \multirow{2}{*}{ No } & \multirow{2}{*}{$\begin{array}{c}\text { Tingkat } \\
\text { Pendidikan }\end{array}$} & \multicolumn{2}{c}{ Kasus } & \multicolumn{2}{c}{ Kontrol } \\
\cline { 3 - 6 } & Rendah & 3 & 42.9 & 9 & 25.7 \\
\hline 1 & Tinggi & 4 & 57.1 & 26 & 74.3 \\
\hline 2 & Total & 7 & $\mathbf{1 0 0}$ & $\mathbf{3 5}$ & $\mathbf{1 0 0}$ \\
\hline
\end{tabular}

Tabel 2

Distribusi kasus dan kontrol berdasarkan tindakan 7T ANC Bidan pada Ibul

\begin{tabular}{cccccc}
\hline No & Standar & \multicolumn{2}{c}{ Kasus } & \multicolumn{3}{c}{ Kontrol } \\
\cline { 3 - 6 } asuhan & Tindakan 7T & $\mathbf{f}$ & $\mathbf{\%}$ & $\mathbf{f}$ & $\%$ \\
\hline 1 & Tidak lengkap & 6 & 85.7 & 18 & 51.4 \\
2 & Lengkap & 1 & 14.3 & 17 & 48.6 \\
\hline & Total & $\mathbf{7}$ & $\mathbf{1 0 0}$ & $\mathbf{3 5}$ & $\mathbf{1 0 0}$ \\
\hline
\end{tabular}


Tabel 5.5

Hasil Analisa Conditional Logistik Regression Tingkat Pendidikan dan Tindakan 7T Bidan Dengan Kematian Maternal di Kota Padang tahun 2017

\begin{tabular}{llllll}
\hline Variabel & $\rho$ Value & OR & & \multicolumn{2}{c}{$95 \%$ CI for $\exp (\mathrm{B})$} \\
\cline { 5 - 6 } & & & & Lower & Upper \\
\hline Pendidikan & 0.065 & 12.814 & & 0.850 & 193.086 \\
7T Bidan & 0.008 & 12.743 & & 0.737 & 220.296 \\
& & & & &
\end{tabular}

Pada Tabel 2 terlihat bahwa standar asuhan $7 \mathrm{~T}$ ANC oleh bidan kepada ibu kasus adalah $6 \mathrm{ibu}(85.7 \%)$ pada saat ANC mendapatkan tindakan $7 \mathrm{~T}$ yang tidak lengkap. Sedangkan dari 35 ibu pada kontrol ada 18 ibu (51.4\%) tidak lengkap mendapatkan standar asuhan 7T ANC ari bidan.Pada Tabel 3 terlihat dari 12 responden yang berpendidikan rendah ada 3 ibu (25\%) yang mengalami kematian maternal serta dari 30 responden yang berpendidikan tinggi ada 4 ibu (13.3\%) mengalami kematian maternal.

Pada tabel 3 menunjukkan hasil analisis bivariat dengan uji Chi-Square didapatkan $\rho$ value $0.038<0.05$ artinya terdapat hubungan yang signifikan antara tingkat pendidikan ibu dengan kematian maternal di kota Padang Tahun 2017. Nilai OR didapatkan sebesar 2.167 yang berarti ibu yang memiliki pendidikan rendah berpeluang 2 kali mengalami kematian maternal. Pada tabel 4 menunjukkan hasil analisis bivariat dengan uji Chi-Square didapatkan $\rho$ Value $0.020<0.05$ artinya terdapat hubungan yang signifikan antara tindakan 7T bidan dengan kematian maternal di kota Padang Tahun 2017. Nilai OR didapatkan sebesar 5.667 yang berarti ibu yang tidak lengkap mendapatkan tindakan 7T dari bidan berpeluang 5 kali mengalami kematian maternal dibanding ibu yang lengkap mendapatkan tindakan 7T dari bidan.

\section{Analisis Multivariat}

Berdasarkan tabel 5.5 didapatkan variabel yang paling berpengaruh terhadap kematian maternal di kota Padang tahun 2017 adalah Tindakan 7T Bidan pada ibu dengan nilai $\rho$ Value paling rendah yaitu 0.008 dengan OR 12.743 dengan rentang CI 95\% (0.737 - 220.296) berarti tindakan 7T bidan mempunyai peluang 12 kali penyebab kematian maternal dibanding ibu yang mengalami status anemia.

\section{Kualitatif}

Input "bagaimana dengan daerah lingkungan kita ini memastikan pelayanan sudah berkualitas ada tidak dalam mencapai kebijakan kesehatan dalam penurunan angka kematian ibu dan bagaimana cara auditnya?"Ada standar ukurnya, ini ada standar terbaru ANC ,SPF terbaru menurut kemenkes RI 2016 sampai dipandu apa itu,SOP nya bagaimana pencapaian kinerjanya, saya rasa semua puskesmas sama."(inf-2R)

"mungkin dari tingkat pengetahuan ibu dan sistem pelayanan kita yang berkesinambungan yang belum maksimal...kendala nya mungkin dari pengetahuan ibu maka nya kita selalu wanti-wanti untuk melakukan kelas ibu hamil, diposyandu seandainya ibu nya tidak ada ,melakukan kunjangan kita akan lakukan kunjungan rumah."(inf-3A). 
"Dinas kesehatan kota padang khususnya kesehatan KIA, program ini mengacu pada pemerintah pusat program KIA ini mengacu ke program kesehatan bumil mulai dari anc, kemudan persalinan atau 58 langkah persalinan, program ibu nifas seperti KN1 sampai KN3, kunjungan neonatal ada standarnya anc juga ada standar sesuai dengan standar dalam acuan, program pemerintah pusat yang kita lakukan di kota padang. Sudah dilaksanakan di kota padang. Kemudian ada program kesehatan anak termasuk bbl, baduta, balita, anak pra sekolah kalau disni lengkap ada uksnya,terkait dengan kematian ibu dan anak tentunya program KIA juga sudah ada kegiatan yang dilakukan untuk itu, contohnya audit perinatal yang dilakukan setiap tahunnya pertemuan manual rujukan yang pertemuannya dilakukan setiap tahunnya. Kemudian ada pelatihan-pelatihan yang mendukung program tersebut ada pelatihan APN, poned 2015, manajemen asfiksia 2016, APN 2017 sudah selesai, ini dalam rangka penurunan angka kematian ibu dan bayi....kalau penyebab langsung kematian ini ada HPP, eklampsia, infeksi itu bagian dari penyebab langsung, tapi factor penyebab dari ibu hamil inikan banyak yaitu kemauan, pendidikan, lingkungan seperti ibu hamil yang berpindah-pindah tempat tinggal. Itulah yang menjadi kendalanya" (inf-6P)

Berdasarkan hasil wawancara sebagian besar informan mengatakan bahwa kebijakan sudah diatur dan ditetapkan langsung oleh pemerintah, namun penjalanan program dari masing-masing puskesmas belum memberikan pelayanan yang maksimal. Salah satu kendala terkait pelaksanaan program yang belum tercapai karena pengetahuan ibu, kemauan, pendidikan ibu serta lingkungan ibu yang berpindah-pindah menyebabkan perilaku kesehatan ibu belum bisa dikatakan sadar kesehatan.

\section{a. Proses}

"bagaimana gambaran secara umum ibu hamil diwilayah yang ibuk bina apakah sering berkonsultasi dengan ibuk, masih banyakah pernikahan dini atau dibawah 20tahun dan berparitas banyak serta jarak kehamilan yang dekat?

"kalau untuk pernikahan dini dikatakan tidak ada, dia ada .tapi dikatakan banyak dia tidak banyak hanya beberapa persen sekitar 5 persen lah kalu kita cakupkan dan kita kumulatifkan dengan rata-rata umur ibu hamil. Dengan paritas yang banyak masih banyak.." (inf-1R)

"gambaran umum ibu hamil di daerah yang saya bina,rata-rata sasaran kita 1 tahun itu sekitar 212 ibu hamil selama setahun. Itu konsultasi nya bukan hanya ke pembina wilayah, kita didaerah perkotaan ini perkelurahan itu nama nya pembina wilayah, jadi untuk konsultasi itu kita ada kunjungan rumah dan juga kita di kota padang ada konsultasi nya ke BPM, ke puskesmas atau ke PUSTU dan secara umumnya kita pantau perkembanganya baik dari segi resti nya,kalau untuk pernikahan dini mungkin tidak terlalu banyak di perkotaan umumnya menikah diatas 20 tahun. Kemudian yang berparitas banyak rata-rata 2 sampai 3 lebih banyak kurang lebih dari 4 mungkin termasuk jarang. "(inf-3A)

"2017 ini ada program dari kemenag yang kerjasama dengan dinas kesehatan. Sudah ada skrining atau kursus catin. Kalau biasanya kursus catin ini materinya $1 x$, sekarang $3 x$ 8jam, kursus catin akan dilaksanakan dikota padang leeadernya depag"(inf-6P)

Berdasarkan hasil wawancara sebagian besar informan mengatakan bahwa masih adanya ibu dengan resiko tinggi (resti) baik 
itu ibu dengan kehamilan karena terlalu muda karena masih adanya pernikahan dibawah umur 20tahun, ada ibu resti dengan kehamilan terlalu tua karena hamil diatas umur produktif (lebih dari 35tahun), masih ada ibu resti dengan jarak kehamilan sebelumnya yang masih dekat atau kurang dari 2tahun atau <24bulan. Dan masih adanya ibu resti dengan terlalu banyak namun rata-rata berparitas 2-3 orang.

\section{b. Output}

\section{"bagaimana penilaian ibuk terhadap} kasus kematian maternal tersebut?"

"kematian maternal tersebut ada 4 Faktor ada 4 T nya,kalau perkotaan 4 T terlambat karna tidak ada transportasikan itu tidak, dia kan ada faktor individunya ada dari faktor tenaga kesehatannya ada dari tempat pelayanan,kalau dari faktor individu kita tingkatkan penyuluhan. Faktor resiko nya seperti ibu hamil resti kita dampingi .sistem rujukan sesuai,yang masalah nya kematian ibu diperkotaan kan banyak di rumah sakit itu yang terlambat. Apakah penanganan di rumah sakit yang terlambat.Tapi bagaimana pun rumah sakit kita lihat lagi kebelakang apakah ANC nya masih kurang berkualitas. "(inf-2R)

"Mungkin dari lintas sektoral dikatakan tidak ada mungkin ada ,tapi untuk kontiniu nya secara berkelanjutan itu yang masih susah kita lakukan walaupun gerakan sayang ibu sudah terbentuk tapi tidak berjalan sebagaimana mestinya,Belum optimal ."(inf-1R)

"Kalau 2 kematian tahun 2016 itu terjadi di rumah sakit, nah kemudian kalau kewajiban kita dalam rangka peningkatan kesejahteraan dan kesehatan ibu khususnya ibu hamil dan ibu bersalin kita punya program KIA contahnya banyak dimulai dari ibu hamil sampai pada nanti ibu itu nifas. Untuk pelaksaan hal itu oleh bidan pada puskesmas ambacang. Masing masing kelurahan itu kita ada pembina wilayah oleh bidan. Kita juga punya beberapa bidan praktek mandiri, yang penting bagi kita bagaimana memberikan kualitas pelayanan pada ANC kemudian persalinan. Kalau kita dipuskesmas ambacang bisa kita ukur bahwa kita telah melaksanakan yang $10 T$ itu, yang kita permasalahkan sekarang kalau untuk khusus di puskesmas ambacang adalah kualitas pelayanan pada bidan praktik mandiri. Kadang kadang mereka tidak sepenuhnya melaksanakan ANC yang standartnya $10 \mathrm{~T}$. Kemudian juga kopentensi mereka, perlengkapan segala macam karena pada saat kita mengadakan supervisi oleh bidan koordinator ada beberapa item yang perlu disikapi yang kadang sampai batas akhir kita melaksanakan supervisi belum mereka laksanakan. Jadi salah satu pendarahan itu bisa disebabkan kematian maternal 2016 itu disebabkan oleh HPP. HPP itu penyebabnya salah satunya bisa karna anemi. Anemi itu tindakan kita salah satunya adalah harus pemeriksaan labor pada masa kehamilan. Itu pada bidan praktek mandiri, ini yang jarang mereka lakukan. Nah seharusnya kalau mereka tidak punya alat itu mereka bisa koordinasi dengan puskesmas dengan menganjurkan ibu hamil itu datang ke puskesmas, khususnya untuk pemeriksaan labor. Kita melayani kok menyiapkan pemeriksaan itu dipuskesmas. Nah inilah yang belum maksimal untuk dijalankan......kejadiaannya di rumah sakit, rujukan kita berjalan barangkali itu penanganan ya tapi itu tergantung lagi iya tapi itu kita tidak punya hak untuk menilai itu, kita tidak bisa menilai karena kita kewajiban kita melaksanakan 10 T, rujukan sampai dengan kelurahan siaga, sampai program $p 4 K$, kelas ibu hamil kita jalankan."(inf-5A) 
"kalau penyebab langsung kematian ini ada HPP, eklampsia, infeksi itu bagian dari penyebab langsung, tapi factor penyebab dari ibu hamil inikan banyak yaitu kemauan, pendidikan, lingkungan seperti ibu hamil yang berpindah-pindah tempat tinggal. Itulah yang menjadi kendalanya"(inf-6P)

Berdasarkan hasil wawancara sebagian besar informan mengatakan bahwa penyebab kejadian kematian maternal terlambat penanganan dan terlambat pemantauan di Rumah Sakit namun bisa karena kebelakangnya pelayanan ANC yang belum berkualitas karena masih banyaknya pemberi layanan tidak menerapkan 10T dalam ANC.

Hal ini juga dipicu karena GSI yang juga belum maksimal sehingga keterlambatan dalam rujukan bisa terjadi. Ditambah untuk pelayanan kedepannya atau untuk kontiniu nya secara berkelanjutan susah dilaksanakan disini bisa dinilai continuum of care belum maksimal ada di masing-masing puskesmas.

"Pak bagaiman di daerah bapak ini menikah dibawah umur 20 tahun pak?"

"...Masyarakat dia masih meyakini fikih munafaat dia belum seratus persen belim meyakini undang-undang no 1 tahun 1974. Kalau seandainya meyakini undangundang itu ini tidak akan terjadi pernikahan dibawah umur,tapi dia masih menerapkan fikih munafaat di benak nya. Karna katanya fikih munafaat tidak ada halangan menikah dibawah umur itu ,hanya jika kalau laki-laki itu dibatas umurnya adalah bermimpi,kalau berperempuan kedatangan bulan. Itu bagi fikih munakaat yang umumnya dikuasai oleh masyarakat muslim pada umumnya. Kalau undang-undang no 1 tahun 1974 tidak boleh menikah selain daripada yang ditentukan oleh undang-undang no 1 tahun
1974 itu yaitu yang pertama laki-laki harus berumur 19 tahun dan perempuan harus yang berumur 16 tahun. Tidak boleh yaitu tidak boleh melebihi umur yang ditetapkan undang-undang no 1 tahun 1974 dan KHI.Kalau seandai dia laki-laki berumur 17 tahun kebawah itu sudah dikatakan pernikahan dini begitu juga perempuan kalau dibawah 15 tahun itu sudah pernikahan dibawah umur.Masyarakat ini tidak tahu membedakan yang dua ini dia berpedoman pada kehendak nafsunya dia tidak mengetahui seluk beluk undangundang tahun 1974. Dan datang orang itu kesini sudah banyak tapi tidak diterima,tidak kami terima orang yang nikah dibawah umur itu. Kenapa karena kami yang kenak,maka kami tolak lah maka dia harus pergi kepengadilan untuk mintak rekomendasi,maka dia baru bisa datang kesini...."(inf-7K)

Berdasarkan hasil wawancara tersebut dapat disimpulkan bahwa penyebab kejadian kematian maternal Pada KUA hubungannya dengan adanya pernikahan di bawah umur 20tahun yaitu dengan adanya kebijakan UU No.1 Tahun 1974 tentang pernikahan yang mengatur usia pernikahan masih adanya masyarakat yang menikah berpedoman pada fikih munafaat yang tidak ada halangan untuk menikah dibawah umur tersebut, mereka dinikahkan setelah mendapatkan surat rekomendasi dan surat dispensasi dari pengadilan agama serta belum adanya tenaga kesehatan dari DKK ataupun nakes Puskesmas dalam pemaparan materi pernikahan dan materi reproduksi untuk para calon pengantin.

\section{Pembahasan}

\section{Analisa Univariat}

\section{Input}

a. Determinan jauh

Berdasarkan hasil wawancara tersebut dapat disimpulkan bahwa kebijakan sudah 
diatur dan ditetapkan langsung oleh pemerintah, namun penjalanan program dari masing-masing puskesmas belum memberikan pelayanan yang maksimal.Salah satu kendala terkait pelaksanaan program yang belum tercapai karena pengetahuan ibu, kemauan, pendidikan ibu serta lingkungan ibu yang berpindah-pindah menyebabkan perilaku kesehatan ibu belum bisa dikatakan sadar kesehatan.Pada KUA juga sudah ada kebijakan yang mendasar yaitu adanya Undang-Undang No 1 tahun 1974 yang mengatur tentang pernikahan.

Pada Tabel 1 terlihat bahwa tingkat pendidikan ibu pada kasus dan kontrol kematianmaternal di Kota Padang tahun2017adalahdari $42 \mathrm{ibu} 12 \quad(28.6 \%)$ ibu dengan tingkat pendidikan rendah.

Hal ini sejalan dengan Hasil Penelitian Nurul Aeni tahun 2013 tentang Faktor resiko kematian ibu menunjukkan bahwa Faktor nonmedis yang mempengaruhi kematian ibu secara tidak lang sung adalah kondisi ekonomi, sosial, dan budaya di lingkungan tempat tinggal ibu hamil.Pada penelitian ini, determinan jauh yang meliputi tingkat pendidikan, status pekerjaan, dan pendapatan keluarga tidak berhubungan dengan kematian ibu. Hasil tersebut berbeda dengan hasil penelitian sebelumnya di Provinsi Nusa Tenggara dimana faktor sosial ekonomi dan demografi, seperti kemiskinan, tingkat pendidikan yang rendah, budaya, bias gender dalam masyarakat, dan keluarga serta lokasi tempat tinggal yang terpencil menyebabkan AKI yang tinggi di daerah tersebut.Persebaran kematian ibu di Kabupaten Pati menunjukkan bahwa jumlah kematian ibu terbanyak tidak terjadi di kecamatan dengan persentase kemiskinan tertinggi. Hal tersebut mengindikasikan bahwa kemiskinan bukan faktor penyebab kematian ibu di Kabupaten
Pati. Program Jaminan Persalinan (Jampersal) menyebabkan akses pemeriksaan kehamilan dan persalinan di tenaga kesehatan terbuka bagi keluarga miskin. Pada penelitian didapatkan masingmasing puskesmas sudah menjalankan program KIA sesuai standarnya. Jika ada kasus rujukan, maka bidan di puskesmas seandainya kasus sudah ditangani di rumah sakit, nakes dipuskesmas akan meminta surat rujukan balik dari rumah sakit kepada pasien. Puskesmas tidak menelantarkan akan hal rujukan balik dari rs

\section{Proses}

\section{Determinan Antara Program KIA}

Berdasarkan hasil wawancara tersebut dapat disimpulkan bahwa masih adanya ibu dengan resiko tinggi (resti) baik itu ibu dengan kehamilan karena terlalu muda karena masih adanya pernikahan dibawah umur 20tahun, ada ibu resti dengan kehamilan terlalu tua karena hamil diatas umur produktif (lebih dari 35tahun), masih ada ibu resti dengan jarak kehamilan sebelumnya yang masih dekat atau kurang dari 2tahun atau <24bulan. Dan masih adanya ibu resti dengan terlalu banyak namun rata-rata berparitas 2-3 orang. Pada Dinas Kesehatan Kota Padang itu sudah direncanakan program lintas sektor dengan Departemen Agama dalam upaya penekanan 3Terlalu ini berupa atau kursus catin yang akan diadakan 3x8jam untuk calon pasangan yang akan menikah.

Pada Tabel 5.2 terlihat bahwa tindakan 7 T ANC oleh bidan kepada ibu kasus dan kontrol kematian maternal di Kota Padang tahun 2017 adalah dari $42 \mathrm{ibu}$ ada $24 \mathrm{ibu}$ $(57.1 \%)$ tidak lengkap mendapatkan tindakan 7T Bidan.

Hasil Penelitian Rahma Kusuma PW, Anneke Suparwati, Putri Asmita W tahun 2016 menunjukkan bahwa Dalam 
pemberian pelayanan Antenatal Care bidan belum sepenuhnya melaksanan pelayanan Antenatal Care Terpadu atau $11 \mathrm{~T}$ masih ada beberapa pemeriksaan yang tidak dilakukan oleh bidan seperti tidak selalu dilakukannya KIE efektif hal ini dikarenakanterbatasnya tenaga dan waktu. Banyaknya ibu hamil yang berkunjung tapi tidak diimbangi dengan terbatasnya jumlah sumber daya manusia yang melakukan pelayanan ANC membuat bidan terkadang lupa untuk memberikan KIE efektif kepada ibu hamil.

Pemeriksaan antenatal adalah pemeriksaan kehamilan yang dilakukan untuk memeriksa keadaan ibu dan janinnya secara berkala, yang diikuti dengan upaya koreksi terhadap penyimpangan yang ditemukan. Pemeriksaan antenatal dilakukan oleh tenaga kesehatan yang terlatih dan terdidik dalam bidang kebidanan, yaitu bidan, dokter dan perawat yang sudah terlatih. Tujuannya adalah untuk menjaga agar ibu hamil dapat melalui masa kehamilan, persalinan dan nifas dengan baik dan selamat. Pemeriksaan antenatal dilakukan minimal 4 kali selama kehamilan, dengan ketentuan satu kali pada trimester pertama (usia kehamilan sebelum 14 minggu), satu kali selama trimester kedua (antara 14 sampai dengan 28 minggu), dan dua kali selama trimester ketiga (antara minggu $28 \mathrm{~s} / \mathrm{d} 36$ minggu dan setelah 36 minggu). Pemeriksaan antenatal dilakukan dengan standar ' 5 T' yang meliputi 1) timbang berat badan, 2) ukur tekanan darah, 3) ukur tinggi fundus uteri, 4) pemberian imunisasi tetanus toksoid, dan 5) pemberian tablet tambah darah 90 tablet selama hamil. (McCarthy dan Maine ,1992)

Menurut asumsi peneliti kualitas pelayanan juga tergantung dari sumber daya manusianya (SDM). Kualitas SDM bisa dinilai dari faktor pengalaman, pengetahuan dan pendidikan. Salah satu dari faktor pengetahuan, umunya semua bidan sudah d3 sesuai kebijakan pemerintah dan organisasi profesi, tapi dilapangan pendidikan saja tidak cukup tanpa diimbangi dengan pembaharuan pengetahuan dan pengalaman seseorang untuk meningkatkan kualitas pelayanan yang diberikan. Disini kesempatan bidan desa untuk mengikuti pembaharuan ilmunya sangat terbatas. Dari penelitian didapatkan bidan desa terakhir mengikuti pelatihan kurang lebih 2 tahun yang lalu, sebisanya bidan desa yang dilapangan yang langsung menyentuh masyarakat ini terus diberi kesempatan untuk mendapatkan pembaharuan ilmu seperti workshop sehari ataupun seminar sehari yang akan sangat membantu para bidan ini untuk meningkatkan kualitas kerjanya.

Pada program KIA antara 2 wilayah puskesmas yang menjadi subjek penelitian, didapat disimpulkan bahwa masing-masing puskesmas sudah menjalankan program masing-masing sesuai kebijakan yang sudah ditetapkan oleh pemerintah. Masingmasing program kerja puskesmas ada SOP dan tujuan yang akan dicapai, namun disini metode dalam menjalankan programlah perbedaannya.

\section{Program KUA}

Berdasarkan hasil wawancara tersebut dapat disimpulkan bahwa pada program KUA terkait hal kesehatan dalam upaya penurunan angka kejadian kematian maternal adalah adanya kebijakan berupa UU No.1 tahun 1974 tentang pernikahan yang menjadi dasar hukum dalam menjalankan program di KUA, sudah adanya kegiatan penceramahan agama untuk setiap calon pasangan yang akan menikah berupa pemberian 10 materi mengenai pernikahan, salah satu syarat untuk bisa dinikahkan oleh KUA adalah 
memperoleh surat keterangan sudah suntik catin yang calon pengantin perempuannya langsung meminta ke puskesmas. Terkait lintas sektor dengan kesehatan itu belum ada, tetapi sudah ada tim dari Unand berupa tim untuk pernikahan yang dihadirkan dalam kegiatan penceramahan untuk calon pasangan yang akan menikah, tetapi ini tidak dari nakes DKK ataupun dari nakes Puskesmas daerah setempat dikarenakan belum adanya program kerjasama lintas sektor dengan nakes juga terkendala dana dan anggaran.

Menurut peneliti program KUA sudah berjalan sebagaimana mestinya kebijakan dari Departemen Agama(Depag), namun pada penelitian ini kaitan program KUA dengan kematian maternal adalah kerjasama lintas sektor KUA dengan KIA. Karena saat akan dinikahkan inilah langkah awal penyuluhan kesehatan reproduksi yang tepat dilakukan karena disini bertemu dengan calon pasangan. Namun sudah diisue kan akan ada suatu program dari depag untuk memberikan arahan tentang kesehatan pada calon pasangan, tentu ini harus ada partisipasi dari dinas kesehatan. Diharapkan ke depannya, program ini bisa terlaksana, dari tenaga kesehatan ikut andil dalam penyuluhan kespro saat penasehatan pernikahan dilakukan sehingga ini bisa sebagai upaya promotif dan preventif kita.

Pada program lintas sektor kesehatan dengan keagamaan khususnya KUA, setelah dilakukan wawancara didapat belum adanya tenaga kesehatann yang terjun dalam skreening langsung memberikan pengarahan langsung kepada calon pasangan yang akan menikah. Dengan adanya kehadiran nakes dalam memberikan konseling ketika penasehatan pernikahan sebelum nikah di KUA diharapkan resiko tinggi dapat diminimalisir dan deteksi dini bisa lebih maksimal dilakukan.
Hal lain menurut pendapat peneliti koordinasi lintas sektor dari KUA ke puskesmas juga mempunyai peran penting dalam pencatatan dan pelaporan. Dimana jika KUA akan menikahkan pasangan berumur <20tahun dan >35tahun hendaknya KUA melaporkan data pasangan tersebut ke Puskesmas wilayah setermpat dimana resiko pada umur tersebut sangat rentan. Sehingga data pasangan usia subur yang akan menikah dan akan menghadapi kehamilan pada umur yang beresiko dapat diterima puskesmas dan diintervensi sedini mungkin oleh nakes di puskesmas dan nakes dapat mengetahui akan ada kehamilan dengan umur yang beresiko sehingga puskesmas bisa memberikan konseling dan penyuluhan terhadap persiapan kehamilan yang tindakan dimulai dari saat imunisasi catin.

\section{Output \\ Determinan Dekat}

Berdasarkanhasilwawancara

tersebutdapatdisimpulkanbahwa penyebab kejadian kematian maternal terlambat penanganan dan terlambat pemantauan di Rumah Sakit namun bisa karena kebelakangnya pelayanan ANC yang belum berkualitas karena masih banyaknya pemberi layanan tidak menerapkan 10T dalam ANC. Pada KUA, adanya kebijakan UU No.1 Tahun 1974 tentang pernikahan yang mengatur usiapernikahan masih adanya masyarakat yang menikah berpedoman pada fikih munafaat yang tidak ada halangan untuk menikah dibawah umur tersebut, mereka dinikahkan setelah mendapatkan surat rekomendasi dan surat dispensasi dari pengadilan agama serta belum adanya tenaga kesehatan dari DKK ataupun nakes Puskesmas dalam pemaparan materi pernikahan dan materi reproduksi untuk para calon pengantin. 
Hasil Penelitian Mohd. Andalas, Ismi Fauzia, Monadilla dan Dean Reza tentang Gambaran kematian maternal di rsud dr. Zainoel abidin selama tahun 2010 dan 2011 menunjukkan bahwa Perdarahan, terutama perdarahan postpartum memberikan kontribusi $25 \%$ pada kematian maternal, khususnya bila ibu menderita anemia akibat keadaan kurang gizi. Sepsis/infeksi memberikan kontribusi $15 \%$ terhadap kematian maternal, yang pada umumnya merupakan akibat dari rendahnya higiene saat proses persalinan atau akibat penyakit menular seksual yang tidak diobati sebelumnya.

Menurut analisis peneliti, penyebab kematian maternal masih tertinggi karena penyebab langsung mencakup kematian ibu akibat penyulit obstetri pada kehamilan,persalinan, atau masa nifas, dan akibat dari intervensi, kelalaian,kesalahan terapi atau rangkaian kejadian yang disebabkan oleh faktor-faktor tersebut. Penyebab langsung kematian maternal di kota Padang masih tertinggi disebabkan oleh Perdarahan, Preeklampsi Berat dan Infeksi. Perdarahan yang terjadi pada masa nifas, dimana kematian akibat perdarahan postpartum ini salah satunya karena keterlambatan penanganan, hal ini mungkin disebabkan karena rasio jumlah pasien dengan rasio jumlah tenaga kesehatan untuk pelayanan tidak sebanding, jadi kurang mengontrol pasien akibatnya terjadilah keterlambatan dalam menanggani perdarahan postpartum pada pasien. Kebelakangnya, kualitas ANC memegang peranan penting dalam kesehatan ibu hamil, disini kematian maternal terjadi juga karena kualitas ANC yang belum maksimal karena belum lengkapnya asuhan yang diberikan pada ibu, yaitu 5T belum berjalan sesuai standar. Hal ini dapat dilihat di buku KIA ibu, dimana masih ada ibu yang tidak diberikan imunisasi TT, pemeriksaan HB ataupun pemeriksaan labor lainnya, masih ada ibu yang tidak diberikan Tablet Fe, juga kurangnya pendidikan kesehatan yang diberikan nakes kepada ibu hamil ketika ANC, hal ini dikatakan oleh saudara atau suami ibu yang menemani ibu ketika ANC, hal ini berarti konseling bidan dirasakan belum maksimal. Dari segi kesehatan ibu itu sendiri, terjadinya perdarahan bisa karena ibu hamil yang anemia. Sebagaimana ditemukan dalam buku KIA rata-rata ibu hamil hanya diperiksa $\mathrm{HB}$ nya 1x selama kehamilan dan banyak ditemui ibu yang anemia, sehingga salah satu pemicu terjadinya perdarahan yang berujung pada kematian maternal.

\section{Tingkat pendidikan}

Pada Tabel 5.3 terlihat dari 12 responden yang berpendidikan rendah ada 3 ibu (25\%) yang mengalami kematian maternal serta dari 30 responden yang berpendidikan tinggi ada 4 ibu (13.3\%) mengalami kematian maternal.

Pada tabel 5.3 menunjukkan hasil analisis bivariat dengan uji Chi-Square didapatkan $\rho$ Value $0.038<0.05$ artinya terdapat hubungan yang signifikan antara tingkat pendidikan ibu dengan kematian maternal di kota Padang Tahun 2017. Nilai OR didapatkan sebesar 2.167 yang berarti ibu yang memiliki pendidikan rendah berpeluang 2 kali mengalami kematian maternal.

Hal ini sejalan dengan penelitian Agho $\mathrm{KE}$, Ezeh OK, Issaka AI, Enoma AI, Baines S, Renzaho AM tahun 2015 tentang Perkiraan risiko yang timbul dari populasi untuk faktor yang terkait dengan penggunaan layanan perawatan pascakelahiran di antara wanita di Nigeria menunjukkan bahwa Layanan PNC nonpenggunaan dikaitkan dengan 68\% (95\% CI $56 \%$ sampai $76 \%$ ) dari ibu yang 
melahirkan di rumah, 61\% (95\% CI 55\% sampai $75 \%$ ) dari mereka yang melahirkan dengan bantuan non- profesional kesehatan dan 37\% (95\% CI 31\% sampai 45\%) dari mereka yang kekurangan pengetahuan tentang komplikasi persalinan pada populasi penelitian. Beberapa analisis variabel menunjukkan bahwa penggunaan layanan $\mathrm{PNC}$ non-ibu di antara ibu dikaitkan secara bermakna dengan tempat tinggal di pedesaan, kemiskinan rumah tangga, tidak ada atau rendahnya tingkat pendidikan formal ibu, ukuran bayi yang dianggap kecil, pengetahuan tentang komplikasi terkait persalinan, dan keterbatasan atau tidak ada akses ke media massa ( BMJ Open,2016).

Menurut analisis peneliti tingkat pendidikan berhubungan langsung dengan kematian maternal adalah semua tergantung tingkat pendidikan seseorang baik itu kesadaran akan kesehatan tergantung pendidikan seseorang, apa yang baik dan buruk yang akan mereka kerjakan terhadap kesehatan mereka tergantung pendidikannya. Namun disini kurangnya masyarakat yang sadar dan peduli akan kesehatan itu lah penyebab yang mempengaruhi seseorang untuk bertindak, kesadaran kesehatan tentunya dipengaruhi dengan adanya pengetahuan kesehatan, nakes memberikan konseling, bidan memberikan konseling saat ANC pada ibu hamil secara lebih optimal lebih berperan penting dalam pengaruh sadar kesehatan masyarakat sehingga kematian maternal dapat diminimalisir.

\section{a. Tindakan $7 \mathrm{~T}$ oleh bidan}

Pada Tabel 5.4 terlihat dari $24 \mathrm{ibu}$ yang tidak lengkap mendapatkan tindakan $7 \mathrm{~T}$ Bidan ada $6 \mathrm{ibu}(25 \%)$ mengalami kematian maternal. Serta dari 18 ibu yang lengkap mendapatkan tindakan 7T Bidan ada 1 ibu (5.6\%) mengalami kematian maternal.

Pada tabel 5.4 menunjukkan hasil analisis bivariat dengan uji Chi-Square didapatkan $\rho$ Value $0.020<0.05$ artinya terdapat hubungan yang signifikan antara tindakan 7T bidan dengan kematian maternal di kota Padang Tahun 2017. Nilai OR didapatkan sebesar 5.667 yang berarti ibu yang tidak lengkap mendapatkan tindakan 7T dari bidan berpeluang $5 \mathrm{kali}$ mengalami kematian maternal dibanding ibu yang lengkap mendapatkan tindakan 7T dari bidan.

Pelayanan/ standar asuhan antenatal care 7T yang diberikan pada pemeriksaan kehamilan, tenaga kesehatan harus memberikan pelayanan yang berkualitas sesuai dengan standar yaitu : Timbang Berat Badan, Ukur Tekanan darah, ukur tinggi fundus uteri, pemberian imunisasi TT lengkap, pemberian tablet besi, tes PMS dan temu wicara (konseling) (Kementrian Kesehatan RI, 2012)

Menurut analisis peneliti tindakan 7T bidan yang kurang didapat pasien adalah temu wicara baik itu dalam persiapan rujukan ataupun saat penemuan kasus hal ini diketahui dari responden kontrol yang mengatakan hal demikian padahal tablet besi diberikan tapi tidak dijelaskan secara detail indikasi dan kontraindikasi akan tablet besi tersebut jika dikonsumsi ibu hamil sehingga banyak ibu yang ketika minum tablet $\mathrm{Fe}$ dan ibu mengalami konstipasi lalu ibu memutuskan tidak mengkonsumsi tablet Fe lagi. Hal ini tentu karena kurangnya pengetahuan ibu terhadap indikasi dari tablet $\mathrm{Fe}$ hal ini dipicu kurangnya konseling dari nakes khususnya bidan di BPS terhadap tatalaksana kasus anemia pada pemberian tablet Fe ini. 
Hal lainnya menurut peneliti yang kurang dilakukan pada 7T ANC adalah tes terhadap pms. Sedangkan pada wawancara dengan salah satu kepala puskesmas didapat bahwa 10T ANC belum optimal. Pada 10T pemeriksaan labor sangat penting dilakukan untuk mengetahui komplikasi yang ada pada ibu hamil. Disini salah satu layanan 10T tidak dilakukan bidan di BPS hal ini bisa disebabkan alat yang kurang lengkap ataupun ketidakdisiplinan nakes itu sendiri karena di BPS tidak adanya monitoring langsung oleh kepala puskesmas dalam pemberian layanan seperti di puskesmas.

Sesuai penelitian Chukwuma A, Wosu AC, Mbachu C, Weze K tahun 2015 tentang Kualitas perawatan antenatal memprediksi retensi pada kehadiran kelahiran terampil: analisis multilevel terhadap 28 negara Afrika menunjukkan bahwa Di antara klien ANC dalam sampel penelitian, $66 \%$ menerima SBA. Menyesuaikan untuk semua kovariat demografi dan indikator negara, kemungkinan retensi pada SBA lebih tinggi di antara klien ANC yang diperiksa tekanan darahnya, mendapat informasi tentang komplikasi kehamilan, tes darah dilakukan, menerima setidaknya satu suntikan tetanus, dan tes urine dilakukan.Kualitas ANC yang lebih tinggi memprediksi retensi SBA di Afrika. Meningkatkan kualitas perawatan terampil yang diterima secara prenatal dapat meningkatkan retensi klien selama melahirkan, mengurangi AKI.(Biomed Central,2017).

Hal ini terkait dengan kematian maternal karena kurangnya kualitas pelayanan dari nakes khususnya bidan dalam pemberian standar asuhan 7T pada ANC. Banyak tes HB hanya dilakukan 1x selama kehamilan oleh bidan. Hal ini tentu kembali ke kualitas pelayanan yang diberikan bidan dalam pelayanan yang kurang optimal.

\section{Analisis Multivariat}

Berdasarkan tabel 5 didapatkan variabel yang paling berpengaruh terhadap kematian maternal di kota Padang tahun 2017 adalah Tindakan 7T Bidan pada ibu dengan nilai $\rho$ Value paling rendah yaitu 0.008 dengan OR 12.743 dengan rentang CI 95\% (0.737 220.296) berarti tindakan $7 \mathrm{~T}$ bidan mempunyai peluang $12 \mathrm{kali}$ penyebab kematian maternal dibanding ibu yang mengalami status anemia.

Hal ini sejalan dengan hasil Penelitian Rahma Kusuma PW, Anneke Suparwati, Putri Asmita W yang berjudul Analisis faktor yang mempengaruhi kinerja bidan dalam pelayanan antenatal care di puskesmas kagok kota semarang tahun 2016 menunjukkan bahwa Dalam pemberian pelayanan Antenatal Care bidan belum sepenuhnya melaksanan pelayanan Antenatal Care Terpadu atau $11 \mathrm{~T}$ masih ada beberapa pemeriksaan yang tidak dilakukan oleh bidan seperti tidak selalu dilakukannya KIE efektif hal ini dikarenakanterbatasnya tenaga dan waktu. Banyaknya ibu hamil yang berkunjung tapi tidak diimbangi dengan terbatasnya jumlah sumber daya manusia yang melakukan pelayanan ANC membuat bidan terkadang lupa untuk memberikan KIE efektif kepada ibu hamil. Terbatasnya jumlah sumber daya manusia yang dimiliki puskesmas Kagok dalam pelayanan ANC masih kurang sesuai dengan Permenkes No 75 Tahun 2014 tentang Pusat Kesehatan Masyarakat jumlah bidan dalam 1wilayah kerja 8 Puskesmas adalah 4orang bidan. Dilihat dari segi sarana dan prasara, didapatkan informasi bahwa sarana dan prasarana di Puskesmas Kagok sudah cukup lengkap dan layak pakai, namun ruang pemeriksaan ibu hamil masih dirasa kurang memadai oleh bidan. Bidan merasa ruangan 
pemeriksaan sempit karena banyaknya perlengkapan untuk melakukan pemeriksaan ibu hamil.

Pemeriksaan antenatal adalah pemeriksaan kehamilan yang dilakukan untuk memeriksa keadaan ibu dan janinnya secara berkala, yang diikuti dengan upaya koreksi terhadap penyimpangan yang ditemukan. Pemeriksaan antenatal dilakukan oleh tenaga kesehatan yang terlatih dan terdidik dalam bidang kebidanan, yaitu bidan, dokter dan perawat yang sudah terlatih. Tujuannya adalah untuk menjaga agar ibu hamil dapat melalui masa kehamilan, persalinan dan nifas dengan baik dan selamat. Pemeriksaan antenatal dilakukan minimal 4 kali selama kehamilan, dengan ketentuan satu kali pada trimester pertama (usia kehamilan sebelum 14 minggu), satu kali selama trimester kedua (antara 14 sampai dengan 28 minggu), dan dua kali selama trimester ketiga (antara minggu 28 s/d 36 minggu dan setelah 36 minggu) (McCarthy dan Maine ,2005).

\section{KESIMPULAN}

Setelah dilakukan penelitian pada tanggal 16 Juni sampai 15 Juli 2017 tentangAnalisis Faktor yang Mempengaruhi Penyebab Kematian Maternal di Kota Padang Tahun 2017 dapat diambil kesimpulan bahwa Proses berupa semua program KIA dan KUA yang merupakan determinan antara pada kasus kematian maternal belum berjalan maksimal. Program KIA yang berupa 7T, 10T terpadu ANC pada masing-masing BPM masih jarang dilakukan. Untuk kunjungan ANC, k4 sesuai target namun k1 masih banyak ditemui ibu tidak tahu kalau hamil sehingga k1 tidak ada Pelaksanaan program KIA lainnya yaitu dalam menangani 4Terlalu dan 3Terlambat yang ada. Meskipun program $\mathrm{KB}$ sesuai target, namun diperlukannya peran serta suami.

\section{DAFTAR PUSTAKA}

Aeni, Nurul. 2013. Faktor Risiko Kematian Ibu. Jurnal Kesehatan Masyarakat Nasional Volume 7 Nomor 10 Mei 2013

Agho KE, Ezeh OK, Issaka AI, Enoma AI, Baines S, Renzaho AM.2015. Population attributable risk estimates for factors associated with non-use of postnatal care services among women in Nigeria. $B M J$ Open 2016

Chukwuma A, Wosu AC, Mbachu C, Weze K.2015. Quality of antenatal care predicts retention in skilled birth attendance: a multilevel analysis of 28 African countries. Biomed Central 2017

Goodman DM, Ramaswamy R, Jeuland M, Srofenyoh EK, Engmann CM, Olufolabi AJ, Owen MD.2017. The Cost effectiveness of a quality improvement program to reduce maternal and fetal mortality in a regional referral hospital in Accra,Ghana. Journal Plos One July 2017.

Goodman DM, Srofenyoh EK, Olufolabi AJ, Kim SM, Owen MD. The birth delay: understanding waiting time for obstetric referrals at a large regional hospital in Ghana. Biomed Central 2017

Guspianto. 2012. Determinan Kepatuhan Bidan di desa terhadap standar Antenatal Care. Jurnal Kesehatan Masyarakat Nasional Volume 7 nomor 2 September 2012.

Hartanto,Hanafi.2002. Keluarga Berencana dan Kontrasepsi. Jakarta: Pustaka Sinar Harapan

http://kua-pauh.blogspot.co.id/p/programkerja.html diakses 27 Agustus 2017 pukul 00.18 WIB

Ika, Arulita Fibriani. 2007. Faktor- Faktor Risiko yang Mempengaruhi Kematian 
Maternal (Studi Kasus di Kabupaten Cilacap). E-Jurnal Undip

Kementrian Kesehatan Republik Indonesia.2014. Profil Kesehatan Indonesia Tahun 2013. Jakarta: Kementrian Kesehatan Republik Indonesia

Kementrian Kesehatan Republik Indonesia.2015. Profil Kesehatan Indonesia Tahun 2014. Jakarta: Kementrian Kesehatan Republik Indonesia

Kusuma, Rahma PW, Anneke Suparwati, Putri Asmita W. 2016. Analisis Faktor yang Mempengaruhi Kinerja Bidan dalam Pelayanan Antenatal Care di Puskesmas Kagok kota Semarang. Jurnal Kesehatan Masyarakat (eJournal) Volume 4 Nomor 4 Oktober 2016.

Lisnawati, Lilis. 2013. Asuhan Kebidanan Terkini Kegawatdaruratan Maternal dan Neonatal. Jakarta : CV. Trans Info Media

Maryunani, Anik, Eka Puspita. 2013. Buku Saku Program Perencanaan Persalinan dan Pencegahan Komplikasi. Jakarta: CV.Trans Info Media.

Mirkovic KR, Lathrop E, Hulland EN, Jean-Louis R, Lauture D, D'Alexis GD, Hanzel E, Grand-Pierre R.2015. Quality and uptake of antenatal and postnatal care in Haiti. BiomedCentral 2017

Paramita, Astridyam Niniek Lely Pratiwi. 2007. Persepsi Organisasi Masyarakat Tentang Konsep Peran Serta Masyarakat dan Kontribusi Organisasi Masyarakat terkait Upaya Akselerasi Penurunan Angka Kematian Ibu dan Angka kematian Bayi. Pusat Penelitian dan Pengembangan Sistem dan Kebijakan Kesehatan volume 10 Nomor 4 Oktober 2007.
Prawihardjo, Sarwono.2010.Ilmu Kandungan.Jakarta : Yayasan Bina Pustaka Sarwono Prawihardjo

Proverawati,Atikah. 2009. Buku Ajar Gizi Untuk Kebidanan. Yogyakarta: Nuha Medika

Saifudin AB, dkk.2009. Buku acuan nasional pelayanan kesehatan maternal dan neonatal.Jakarta: yayasan Bina Pustaka Sarwono Prawirohardjo.

Sugiyono.2014.Metode Penelitian Manajemen. Bandung: Alfabeta

Sugiyono.2016.Metode Penelitian Kuantitatif kualitatif, dan $R \& D$. Bandung :Alfabeta. 